\title{
EPISTEMOLOGI HUKUM (YANG) SUBJEKTIF SEBAGAI JALAN MEWUJUDKAN HUKUM YANG BERPERI-KEMANUSIAAN
}

\author{
Aditya Yuli Sulistyawan \\ Fakultas Hukum Universitas Diponegoro Semarang \\ Email: adityayuli38@gmail.com
}

\begin{abstract}
Abstrak
Penegakan hukum yang dipengaruhi oleh dominasi paradigma positivisme memaparkan potret penegakan hukum yang tidak berperi-kemanusiaan karena dianggap tidak mengedepankan keadilan, khususnya bagi rakyat kecil. Kasus-kasus hukum seperti pencurian tiga biji kakao oleh Nenek Minah di Banyumas, pencurian setandan pisang oleh Mbah Klijo di Yogyakarta hingga kasus Baiq Nuril yang oleh Putusan MA divonis bersalah melanggar UU ITE. Sepertinya hukum memang tidak didesain untuk memanusiakan manusia. Penegak hukum seperti hanya menjalankan tugasnya untuk merealisasikan teks-teks semata, sekaligus di saat yang sama mengabaikan konteksnya. Ciri demikian sejatinya adalah hakikat hukum yang ber-ontologi realisme naif sebagaimana diyakini oleh pemeluk paradigma positivisme dalam memaknai realitas. Melihat kenyataan paradigmatik yang ada, sejatinya hukum yang ber-epistemologi subjektif adalah sebuah tawaran untuk mewujudkan hukum yang berperikemanusiaan. Apa dan bagaimanakah paradigma yang memberi kemungkinan mewujudkan itu adalah permasalahan yang akan dibahas dalam tulisan ini. Melalui tradisi kualitatif dan paradigma yang menuntun penulis, pembahasan atas permasalahan ini menghadirkan jawaban pada pilihan dua paradigma yang berepistemologi subjektif, yakni: Critical Theory et. al. atau Konstruktivisme. Lantas, perlukah kemudian terjadi shifting paradigm sebagai solusi (?).
\end{abstract}

Kata Kunci: epistemologi, subjektif, hukum yang berperi-kemanusiaan, paradigma.

\section{A. Pendahuluan}

Persoalan penegakan hukum di Indonesia yang dianggap tidak adil bagi 'wong cilik' hampir selalu terjadi dan menarik perhatian publik. Masyarakat luas menyorot berbagai kasus yang setidaknya disajikan oleh media massa mengenai penegakan hukum atas kasus-kasus hukum yang melibatkan 'wong cilik' dan dinilai tidak berperi-kemanusiaan itu. Beberapa di antaranya adalah: ${ }^{1}$

1) Pencurian sebuah semangka yang dilakukan Basar Suyanto dan Kholil pada tahun 2009 (vonis bersalah oleh Pengadilan Negeri Kediri dengan hukuman 2 bulan 10 hari);

2) Seorang wanita tua penjual petasan bernama Meri, asal Tegal yang harus dihukum penjara selama 3 bulan dengan masa percobaan 6 bulan, karena kedapatan menjual petasan di rumahnya, sementara ia tidak tahu kalau menjual petasan itu dilarang hukum karena ia sudah berjualan petasan sejak lama; 3) Seorang buruh tani di Serang, Banten bernama Aspuri harus berurusan dengan hukum karena memungut sebuah kaus lusuh di

1 Diah, 7 Kasus Hukum di Indonesia yang "Terkesan Tajam ke Bawah, Tumpul ke Atas", https://www.boombastis.com/hukum-di-indonesia/58772, diakses pada 29 Maret 2019. 
pagar rumah tetangganya; 4) Seorang nenek Minah harus menjalani hukuman 1 bulan penjara dengan masa percobaan 3 bulan karena terbukti mencuri 3 buah kakao seharga Rp 2.000,- milik PT Rumpun Sari Antan yang di Banyumas; 5) Seorang nenek Asyani yang diduga mencuri tujuh batang katu jati milik Perum Perhutani harus mendekam di penjara selama masa tahanan dan menjalani hukuman pidana atas perbuatannya; 6) Seorang kakek tua berusia 76 tahun di Godean, Yogyakarta bernama Klijo harus berhadapan dengan hukum karena dituduh mencuri setandan pisang seharga Rp. 2.000,; 7) Seorang Baiq Nuril yang dinyatakan bersalah oleh majelis hakim tingkat kasasi di Mahkamah Agung berdasarkan Pasal 27 (1) Undang-Undang Informasi dan Transaksi Elektronik, padahal sejatinya ia adalah korban pelecehan seksual yang dilakukan atasannya.

Berbagai kritik terhadap penegakan hukum seperti pada kasus-kasus di atas kerap kali dilontarkan oleh publik. Masyarakat sering merasa kecewa terhadap proses penegakan hukum yang sering bersifat tidak adil, berat sebelah, dan selalu pada posisi timpang terhadap mereka yang lemah. Dalil bahwa "hukum bak pisau, tajam ke bawah dan tumpul ke atas” menjadi penjelasan utama terhadap realitas penegakan hukum yang terjadi.

Di bawah dominasi pengaruh paradigma positivisme sebagaimana pola yang diajarkan di berbagai level pendidikan dan pada lazimnya giat kehidupan yang terlanjur memercayai kebenaran sebab-akibat, masyarakat luas masih sangat berharap hukum bisa menjunjung prinsip objektifitas. Mereka seolah ingin meletakkan harapan itu kepada (jiwa-jiwa) manusia yang adalah 'human' itu. Ekspektasi mereka terhadap hukum adalah kemampuannya untuk menghukum siapapun yang bersalah atau melanggar hukum itu, tidak terkecuali - sebagaimana sifat objektif itu sendiri maka hukum diselenggarakan sesuai kehendak objeknya, dalam hal ini teks-teks peraturan menentukan segala makna dari hukum itu.

Padahal, jika hukum dipahami dalam bingkai paradigma positivisme seperti itu, maka tidak salah mestinya jika 'wong cilik' harus dihukum jika memang terbukti melanggar hukum, sama dengan kondisi sebaliknya jika orang kaya, pejabat, atau siapapun dia yang melanggar hukum juga harus dihukum. Namun, kenyataan hukum sebagaimana dijabarkan melalui penegakan hukum pada beberapa kasus di atas, seolah menunjukkan bahwa masyarakat menghendaki bahwa hukum semestinya memihak kepada mereka yang lemah. Suatu kondisi kontradiktif dengan harapan mereka atas objektifitas.

Positivisme secara implisit hanya mereduksi ilmu pengetahuan pada ilmu-ilmu pasti (eksakta) dan secara vulgar mempertahankan status quo ilmu-ilmu sains yang hebat dan kredibel. Sementara itu, pemeriksaan terhadap pengetahuan lainnya seperti refleksi kritis pengetahuan humanis, jelas tidak ada dalam kamus positivisme. Konsep hukum yang di-alirkan oleh 
positivisme hukum menampilkan sosok hukum yang sedemikian rupa objektif, tersedia dalam pemaknaan yang disampaikan oleh tulisan-tulisan peraturan sebagai objek yang independen. Hukum juga merupakan closed logical system, yang berarti peraturan dapat dideduksikan dari undang-undang yang berlaku tanpa perlu meminta bimbingan dari norma sosial, politik dan moral.

Persoalan pemaknaan terhadap hukum sejatinya adalah wilayah filsafat daripada hukum. Adalah tugas penulis, selaku akademisi yang berkecimpung di dunia Filsafat Hukum, untuk memberikan penjelasan kepada publik agar pandangan skeptis mereka terhadap hukum tidak lestari, agar kasus-kasus penegakan hukum yang terjadi dapat lebih terpahami, baik secara hakikatnya, epistemologinya, hingga metode penyelesaian yang digunakan sesuai paradigmanya, sebagai pengejawantahan dari 'set basic belief' penganutnya.

Ketika proses penegakan hukum yang menampilkan potret 'wong cilik' dihukum, masyarakat seolah ingin menawar objektifitas, berharap hukum berlaku memihak kepada mereka. Padahal menurut pemahaman paradigma Guba dan Lincoln, kata objektif adalah kata kunci yang melandasi ontologi dan epistemologi paradigma positivisme. Lantas, bagaimanakah jalan untuk mewujudkan hukum yang berperikemanusiaan itu sebagaimana harapan publik, apakah ada epistemologi lain yang ditawarkan oleh paradigma lainnya untuk mewujudkan hukum yang berperikemanusiaan itu? Pertanyaan tersebut merupakan pokok permasalahan yang akan dibahas dalam paper ini, hingga di paling ujung nantinya sampai kepada pertanyaan tentang perlu tidaknya shifting paradigm menjadi pilihan.

Sebelum sampai kepada pembahasan, penulis akan menunjukkan akuntabilitas keilmuan penulis melalui proses penelitian yang memandu giat penulis dalam penelitian, penulisan, dan penuangan setiap hasil pemikiran dalam paper ini. Pertama, tradisi penelitian (yang berbicara mengenai standpoint atau titik pandang peneliti terhadap objek penelitian) yang digunakan penulis dalam paper ini adalah tradisi kualitatif. Menurut Kirk dan Miller sebagaimana dikutip oleh Lexy J. Moleong, istilah penelitian kualitatif pada mulanya bersumber pada pengamatan kualitatif yang dipertentangkan dengan pengamatan kuantitatif. ${ }^{2}$

Sementara itu, berdasarkan gagasan paradigma Guba dan Lincoln, dalam penulisan ini, penulis menggunakan paradigma konstruktivisme sebagai 'pisau analisis'. Adapun jawaban atas

\footnotetext{
${ }^{2}$ Kirk dan Miller dalam Lexy J. Moleong, Metodologi Penelitian Kualitatif, (Bandung: Remaja Rosdakarya, 2007), 2 . 
pertanyaan ontologis dari paradigma konstruktivisme adalah relativisme, jawaban atas pertanyaan epistemologis dari paradigma ini adalah transaksional/subjektif, serta jawaban atas pertanyaan metodologis dari paradigma ini adalah hermeneutikal/dialektikal. ${ }^{3}$

\section{B. Pembahasan}

Sebelum lebih lanjut membahas mengenai epistemologi realitas hukum yang objektif maupun yang subjektif, sebelumnya penulis perlu menjelaskan bahwa telaah epistemologi yang dimaksud merupakan salah satu 'set basic belief' yang merupakan representasi dari paradigma tertentu. Maka dalam sub-bab ini penulis akan mulai menjelaskan dengan pemahaman tentang paradigma. Paradigma merupakan bagian daripada filsafat, karena ia merupakan filsafat utama, induk, atau 'payung' sebagaimana ditegaskan N.K. Denzin dan Y.S. Lincoln dalam pengertian paradigma, yakni: ${ }^{4}$

Paradigma adalah suatu sistem filosofis utama, induk, atau 'payung' yang terbangun dari ontologi, epistemologi, dan metodologi tertentu, yang masing-masingnya terdiri dari satu 'set' belief dasar atau worldview yang tidak dapat begitu saja dipertukarkan [dengan belief dasar atau worldview dari ontologi, epistemologi, dan metodologi paradigma lainnya]. Paradigma mem-presentasi- kan suatu sistem atau set belief 'dasar' tertentu yang berkenaan dengan prinsip-prinsip utama atau pertama, yang mengikatkan penganut/penggunanya pada world-view tertentu, berikut cara bagaimana 'dunia' harus dipahami dan dipelajari, serta yang senantiasa memandu setiap pikiran, sikap, kata, dan perbuatan penganutnya.

Dari sekian banyak pakar yang menawarkan pemahaman berikut klasifikasi paradigma, penulis cenderung mengadopsi pendapat Guba dan Lincoln yang menurut Erlyn Indarti lebih mencakup sekaligus sistematis, padat, dan rasional. Mereka, yang pada dasarnya lebih condong kepada pengertian global dari paradigma itu, membedakan paradigma berdasarkan pada jawaban masing-masing terhadap 3 (tiga) 'pertanyaan mendasar' yang menyangkut: ${ }^{5}$

a. bentuk dan sifat realitas, berikut apa yang dapat diketahui mengenai hal ini [disebut sebagai pertanyaan 'ontologis'];

b. sifat hubungan atau relasi antara individu atau kelompok masyarakat dengan lingkungan atau segala yang ada di luar diri-nya, termasuk apa yang dapat diketahui tentang hal ini [disebut sebagai pertanyaan 'epistemologis', ke dalam mana termasuk pula pertanyaan 'aksiologis']; dan

\footnotetext{
${ }^{3}$ Egon G. Guba \& Yvonna S. Lincoln dalam Norman K. Denzin \& Yvonna S. Lincoln (ed), The Sage Handbook of Qualitative Research 1 Third Edition (Yogyakarta: Pustaka Pelajar, 2011), 209.

${ }^{4}$ Erlyn Indarti, Diskresi dan Paradigma: Suatu Telaah Filsafat Hukum, Pidato Pengukuhan Guru Besar Universitas Diponegoro (Semarang: Badan Penerbit Undip, 2010).

${ }^{5}$ Ibid.
} 
c. cara bagaimana individu atau kelompok masyarakat [tentunya termasuk peneliti] mendapatkan jawab atas apa yang ingin diketahuinya tersebut [disebut sebagai pertanyaan 'metodologis'].

Dalam konteks pengertian paradigma inilah, Guba dan Lincoln menawarkan 4 (empat) paradigma utama. Keempat paradigma dimaksud adalah : positivism; postpositivism; critical theory et al; dan constructivism. Keempat paradigma tersebut dibedakan satu sama lain melalui respon terhadap 3 (tiga) pertanyaan mendasar; yang meliputi pertanyaan 'ontologis', 'epistemologis', dan 'metodologis'. Berikut ini adalah 'Set Basic Belief dari keempat paradigma utama yang ditawarkan oleh Guba dan Lincoln tersebut: ${ }^{6}$

Tabel 1. Set Basic Belief 4 (empat) Paradigma Utama

\begin{tabular}{|c|c|c|c|c|}
\hline Pertanyaan & Positivisme & Postpositivisme & Critical Theory et al & Konstruktivisme \\
\hline \multirow[b]{2}{*}{ Ontologi } & Realisme Naif : & Realisme Kritis: & Realisme Historis : & Relativisme: \\
\hline & $\begin{array}{c}\text { realitas } \\
\text { eksternal, } \\
\text { objektif, real, } \\
\text { dan dapat } \\
\text { dipahami. }\end{array}$ & $\begin{array}{l}\text { realitas } \\
\text { eksternal, } \\
\text { objektif, dan } \\
\text { real yang } \\
\text { dipahami scr } \\
\text { tidak } \\
\text { sempurna. }\end{array}$ & $\begin{array}{c}\text { realitas 'virtual' } \\
\text { yang terbentuk } \\
\text { oleh faktor sosial, } \\
\text { politik, budaya, } \\
\text { ekonomi, etnis, dan } \\
\text { 'gender'. }\end{array}$ & $\begin{array}{c}\text { realitas } \\
\text { majemuk \& be- } \\
\text { ragam, } \\
\text { berdasarkan } \\
\text { pengalaman } \\
\text { sosial- } \\
\text { individual, } \\
\text { lokal, dan } \\
\text { spesifik. }\end{array}$ \\
\hline \multirow[b]{3}{*}{ Epistemologi } & $\begin{array}{c}\text { Dualis / } \\
\text { Objektivis : }\end{array}$ & Modifikasi & $\begin{array}{c}\text { Transaksional / } \\
\text { Subjektivis : }\end{array}$ & $\begin{array}{l}\text { Transaksional / } \\
\text { Subjektivis : }\end{array}$ \\
\hline & & Objektivis : & \multirow[b]{2}{*}{$\begin{array}{l}\text { peneliti dan objek } \\
\text { investigasi terkait } \\
\text { scr interaktif; } \\
\text { temuan di- } \\
\text { 'mediasi' oleh nilai } \\
\text { yang dipegang } \\
\text { semua pihak. }\end{array}$} & \multirow[b]{2}{*}{$\begin{array}{l}\text { peneliti dan } \\
\text { objek } \\
\text { investigasi } \\
\text { terkait secara } \\
\text { interaktif; } \\
\text { temuan di- } \\
\text { 'cipta'/ di- } \\
\text { 'konstruksi' } \\
\text { bersama. }\end{array}$} \\
\hline & $\begin{array}{l}\text { peneliti dan } \\
\text { objek investigasi } \\
\text { adalah dua entity } \\
\text { independen; } \\
\text { bebas nilai. }\end{array}$ & $\begin{array}{c}\text { dualisme surut } \\
\text { dan } \\
\text { objektivitas } \\
\text { menjadi } \\
\text { kriteria } \\
\text { penentu; } \\
\text { eksternal } \\
\text { objektivitas. }\end{array}$ & & \\
\hline Metodologi & $\begin{array}{l}\text { Eksperimental / } \\
\text { Manipulatif : }\end{array}$ & $\begin{array}{c}\text { Modifikasi } \\
\text { Eksperimental / } \\
\text { Manipulatif : }\end{array}$ & $\begin{array}{c}\text { Dialogis / } \\
\text { Dialektikal : }\end{array}$ & $\begin{array}{l}\text { Hermeneutikal } \\
\text { / Dialektikal : }\end{array}$ \\
\hline
\end{tabular}

${ }^{6}$ Ibid. 


\begin{tabular}{cccc}
\hline uji empiris dan & falsifikasi & ada 'dialog' antara & 'konstruksi' \\
verifikasi & dengan cara & peneliti dengan & ditelusuri \\
research & critical & objek investigasi, & melalui \\
question dan & multiplism atau & bersifat dialektikal & interaksi antara \\
hipotesa; & modifikasi & : men-'transform' & peneliti dan \\
manipulasi dan & 'triangulasi'; & kemasa-bodohan & objek \\
kontrol terhadap & utilisasi teknik & dan kesalah- & investigasi; \\
kondisi & kualitatif: & pahaman menjadi & dengan teknik \\
berlawanan; & setting lebih & kesadaran untuk & hermeneutikal \\
utamanya & natural, & mendobrak. & dan pertukaran \\
metoda & informasi lebih & & dialektikal \\
kuantitatif. & situasional, dan & & 'konstruksi' di- \\
& cara pandang & & interpretasi; \\
& emic. & & tujuan : distilasi \\
& & & / konsensus / \\
& & & resultante.
\end{tabular}

Sumber : Guba dan Lincoln (1994)

Berdasarkan empat paradigma utama tersebut, akan terlihat jelas hakikat hukum terjabar secara berbeda pada masing-masing paradigma menurut ontologinya. Paradigma positivisme misalnya, hukum dimaknai sebagai realitas naif yaitu realitas eksternal, objektif, real, dan dapat dipahami. Dalam pemaknaan ontologis yang seperti itu, maka hukum tidak lain adalah peraturanperaturan tertulis, seperti Undang-Undang dan peraturan lain yang berwujud teks. Kebenaran realitas dalam paradigma ini berposisi objektif terhadap subjeknya sebagaimana epistemologinya yang 'dualis/objektivis'. Semakin jauh jarak antara subjek dengan hukum tertulis, maka akan semakin objektif penegakan hukum yang dihasilkan.

Dengan pemahaman seperti itu, penegakan hukum pada beberapa kasus hukum sebagaimana dipaparkan di bagian awal paper ini menjadi lazim adanya. Mereka yang bersalah atau melanggar hukum, termasuk kaum 'wong cilik' sekalipun, harus dihukum. Kebenaran dalam 'cara pandang' paradigma positivisme ini menunjukkan kesahihan relasi antara subjek dengan objek/realitas (dalam bingkai epistemologinya) yang objektif. Melalui objektifitas yang dijunjung tinggi ini, nilai-nilai moral yang bersumber dari hati nurani dan rasa kemanusiaan menjadi tidak lagi perlu dibahas. Hukum tinggal diimplementasikan sesuai teksnya, persoalan peri-kemanusiaan manusia yang menjalankan hukum, tak punya ruangnya. Kalau begini, sejatinya tidak perlu manusia yang menyelenggarakan hukum, robot atau mesin juga bisa, karena 
'human' sedang tidak lagi bisa memasukkan 'humanity'-nya. Dalam hal ini hukum itu kemudian berada di wilayah yang esoteris, terisolasi dan terasing dari masyarakat awam. ${ }^{7}$

Hans Kelsen menyebutkan bahwa positivisme hukum menganggap pembicaraan moral, nilai-nilai telah selesai dan final manakala sampai pada pembentukan hukum positif. Oleh karena itulah penggalan kata-kata yang sangat terkenal dari Hans Kelsen: hukum ditaati bukan karena dinilai baik atau adil, tetapi karena hukum itu telah ditulis dan disahkan penguasa. Inilah salah satu teori yang diperkenalkan Hans Kelsen dengan nama Teori Hukum Murni. ${ }^{8}$

Dalam upaya kontrol objektifitas yang seperti itu, hukum sulit menemukan ruang subjektifitasnya ketika berhadapan dengan kasus hukum dengan konteks yang berbeda-beda. Lantas hukum akan berperan netral dan seragam, sesuai teks yang ada, tanpa mengindahkan konteks-konteks kemanusiaan ketika diimplementasikan. Jika 'nature' paradigma yang seperti ini tidak menampilkan hukum yang berperi-kemanusiaan, maka paradigma lain memberi jalan kepada epistemologinya yang subjektif - yang membuka ruang luas untuk menerapkan hukum yang sesuai dengan kebenaran subjektif. Kedua paradigma itu adalah Critical Theory et. al dan Konstruktivisme.

Sebelum tiba kepada pembahasan kedua paradigma yang berepistemologi subjektif tersebut, sebetulnya ada paradigma lain yang menerapkan epistemologi modifikasi dualis/objektivis, yakni Post-Positivisme. Namun, pemaknaan realitas secara lebih kritis menurut paradigma ini tetap dibatasi oleh objektivitas sebagai kriteria penentu. Artinya hukum sekali lagi adalah berwujud teks-teks normatif.

Sementara, dua paradigma utama yang lain, yaitu Critical Theory et. al dan Konstruktivisme sudah mulai beranjak meninggalkan epistemologinya yang objektif menjadi subjektif. Dalam hal ini, subjek atau penganut/pemegang paradigma tersebut sangat menentukan pemahaman terhadap realitas. Dalam konteks subjektifitas yang diterapkan subjek yang adalah 'human', terbuka tempat untuk 'humanity' dimana paradigma konstruktivisme menghadirkan ruang terluas untuk itu.

Pembahasan paradigma berepistemologi subjektif kita mulai dari paradigma Critical Theory et.al. Realitas hukum dimaknakan sebagai realisme historis yang adalah realitas virtual yang dipengaruhi oleh faktor-faktor tertentu di sepanjang sejarah terbentuknya hingga kemudian

\footnotetext{
${ }^{7}$ Satjipto Rahardjo, Hukum dan Perilaku: Hidup Baik Adalah Dasar Hukum yang Baik (Jakarta: Penerbit Kompas, 2009), 3 .

${ }^{8}$ Adji Samekto, Pergeseran Pemikiran Hukum dari Era Yunani Menuju Postmodernisme (Jakarta: Konstitusi Press, 2015), 79-80. 
dianggap real dan diterima benar. Padahal hukum adalah realitas yang senantiasa bersifat memihak kepada mereka yang berkuasa, menindas yang lemah, opresif, dan diskriminatif kepada mereka yang lemah, miskin, perempuan, dan kelompok tertindas. Dalam hal ini epistemologi critical theory et.al. adalah transaksional/subjektivis, atau realitas akan sangat bersifat subjektif bagi seorang critical theorist. Mereka-mereka yang bernaung dalam paradigma ini selalu berupaya melakukan aksi nyata sebagai metode untuk membongkar realitas yang selama ini telah melembaga menjadi seolah benar. Hukum misalnya, peraturan tertulis yang ada senantiasa dianggap sebagai sesuatu yang salah dan harus dibongkar, karena hukum dipengaruhi oleh faktor-faktor tertentu yang menjadikannya timpang dan menindas 'wong cilik'.

Dalam kasus-kasus hukum yang mendera orang miskin, lemah, perempuan, atau 'wong cilik' sebagaimana dipaparkan di awal paper ini, maka implementasi paradigma ini akan menunjukkan subjektifitasnya, sedemikian rupa memihak mereka yang lemah, dikarenakan hukum yang ada adalah realitas yang 'bukan' dan harus dibongkar karena sarat dengan faktor-faktor yang melingkupi saat pembuatannya (misalnya pengaruh faktor ekonomi membuat hukum sedemikian rupa memasukkan kepentingan mereka-mereka yang punya kapital, sehingga menindas yang miskin). Belief yang seperti ini kemudian akan melahirkan perjuangan dalam upaya membela yang lemah atau 'wong cilik'.

Sementara itu, realitas dalam paradigma konstruktivisme dimaknakan secara relatif sebagaimana ontologinya yang ditunjukkan pada tabel di atas. Dengan epistemologi yang juga 'transaksional/subjektivis', pemahaman terhadap hukum akan bersifat sangat subjektif tergantung subjeknya, berdasarkan konstruksi mental yang ditentukan oleh pengalaman sosial individual masing-masing, lokal, dan spesifik. Dengan demikian, secara metodologis realitas hukum akan terwujud melalui penafsiran demi penafsiran yang sangat subjektif hingga kemudian dalam penyelesaian kasusnya membutuhkan suatu konsensus sebagai resultante kesepakatan dari pemikiran masing-masing pihak yang subjektif tersebut.

Melalui ontologinya yang relatif dan epistemologinya yang subjektif, sesungguhnya ruang perikemanusiaan dari manusia penganut paradigma ini, dapat diikut-sertakan. Hukum dalam telaah paradigma ini juga menampilkan sifatnya yang demokratis karena mengedepankan dialog untuk mencapai sebuah kesepakatan.

Dalam konteks kasus-kasus hukum yang penulis sajikan di awal paper ini, upaya penyelesaian perkara berbasis dialog menjadi jalan keluar untuk mewujudkan keadilan bagi pihak-pihak yang terkait, baik pelaku maupun korban. Hukum menjadi lebih humanis karena mengedepankan konteksnya, juga menampung subjektifitas dari semua pihak yang terkait. Jurnal Hukum Progresif, Vol. 7, No. 1, April 2019 
Hukum memainkan sifatnya yang bottom-up, lokal dan spesifik. Jalan mewujudkan hukum yang berperi-kemanusiaan niscaya akan dapat direalisasikan karena subjektifitas menjadi penentu disini.

Di akhir paper ini, pertanyaan lanjutan mengenai apakah perlu dilakukan shifting paradigm untuk dapat mewujudkan hukum yang berperi-kemanusiaan itu, perlu dijawab. A paradigm shift atau perubahan paradigma pada diri seseorang dapat saja terjadi karena sebuah momentum yang terjadi secara alamiah melalui dinamika pemahaman yang dilaluinya. Maka, apakah positivisme atau positivisme sebagai paradigma akan ditinggalkan oleh para penganutnya untuk menuju perubahan mewujudkan hukum yang berperi-kemanusiaan? Tentu saja tidak. Pada masa yang sama, semua penganut paradigma akan saling mewarnai dunia. Positivisme akan tetap memiliki penganutnya, begitupun Post-Positivisme karena kebenaran realitas bagi mereka adalah realitas yang eksternal, riil, objektif dan berepistemologi dualis/objektif ataupun modifikasinya. Di saat yang sama, ada penganut paradigma lainnya yang berepistemologi subjektif, yaitu paradigma Critical Theory et. al dan Konstruktivisme, yang juga memegang kebenaran versi mereka, yang khas menurut ontologinya.

Dengan demikian, kebenaran sejatinya adalah jamak sejumlah paradigma yang ada. Definisi peri-kemanusiaan pun jamak. Bagi mereka yang berparadigma Positivisme pun dapat saja berargumentasi bahwa peri-kemanusiaan bukan sesuatu yang ditinggalkan karena sudah tertampung dalam wujud peraturan, dan dipertimbangkan saat proses pembuatan peraturan tersebut. Hanya saja, sejak peraturan itu dilembagakan maka prinsip objektifitas menjadi harga mutlak, untuk mewujudkan keadilan positivisme. Sementara dua paradigma lain yakni Critical Theory et. al. dan Konstruktivisme yang berepistemologi subjektif senantiasa menyediakan ruang nilai bagi penganutnya untuk memaknai hukum.

\section{Penutup}

Berdasarkan uraian sebelumnya, di akhir tulisan ini penulis dapat menarik simpulan bahwa penentuan mengenai cara berhukum yang ideal akan sangat ditentukan oleh paradigma seseorang. Uraian ontologis, epistemologis, dan metodologis dari keempat paradigma utama merupakan 'set basic belief' yang menuntun manusia dalam memaknai realitas, termasuk hukum. Sebagai salah satu pertanyaan pokok, epistemologi menjadi pembanding diantara empat paradigma yang eksis, diantaranya tertuju kepada pertanyaan "apakah epistemologi hukum yang objektif atau subjektif yang mampu mewujudkan hukum yang berperi-kemanusiaan?" Maka 
jawaban atas pertanyaan ini akan kembali pada epistemologi empat paradigma sebagaimana dijabarkan Guba dan Lincoln tersebut. Positivisme dan Post-Positivisme sebagai dua paradigma utama yang berepistemologi objektif, sementara Critical Theory et. al. dan Konstruktivisme sebagai dua paradigma lainnya yang berepistemologi subjektif. Tentu saja, dari perbandingan epistemologi objektif dan subjektif ini, maka ruang 'humanity' akan lebih mendapat tempat pada sifat epistemologi yang subjektif. Manusia sebagai subjek tentunya memiliki rasa kemanusiaan, sehingga subjektifitas itu senantiasa akan mempengaruhi pemaknaan realitas hukumnya. Hal ini akan dapat diakomodir dalam implementasi paradigma Critical Theory et. al. dan paradigma Konstruktivisme, sehingga dapat disimpulkan bahwa epistemologi hukum (yang) subjektif merupakan jalan untuk mewujudkan hukum yang berperi-kemanusiaan.

\section{DAFTAR PUSTAKA}

Denzin, Norman K. \& Lincoln, Yvonna S.(ed). The Sage Handbook of Qualitative Research 1 Third Edition. Yogyakarta: Pustaka Pelajar, 2011.

Diah, 7 Kasus Hukum di Indonesia yang "Terkesan Tajam ke Bawah, Tumpul ke Atas", https://www.boombastis.com/hukum-di-indonesia/58772, diakses pada 29 Maret 2019.

Indarti, Erlyn. Diskresi dan Paradigma: Suatu Telaah Filsafat Hukum, Pidato Pengukuhan Guru Besar Universitas Diponegoro. Semarang: Badan Penerbit Undip, 2010.

Moleong, Lexy J. Metodologi Penelitian Kualitatif. Bandung: Remaja Rosdakarya, 2007.

Prasetyo, Teguh \& Barkatullah, Abdul Halim. Filsafat, Teori, dan Ilmu Hukum: Pemikiran Menuju Masyarakat yang Berkeadilan dan Bermartabat. Jakarta: Rajagrafindo Persada, 2013.

Rahardjo, Satjipto. Hukum dan Perilaku: Hidup Baik Adalah Dasar Hukum yang Baik. Jakarta: Penerbit Kompas, 2009.

Rato, Dominikus. Filsafat Hukum: Mencari, Menemukan, dan Memahami Hukum. Yogyakarta: LaksBang Justitia, 2010.

Samekto, Adji. Pergeseran Pemikiran Hukum dari Era Yunani Menuju Postmodernisme. Jakarta: Konstitusi Press, 2015.

Sulistyawan, AY. "Mempersoalkan Objektivitas Hukum: Suatu Perbincangan Filsafat Hukum". Jurnal Masalah-Masalah Hukum Vol. 41, No. 4, Tahun 2012. 